\title{
Comments to Angulo et al. 2016 on "Sea-level fluctuations and coastal evolution in the state of Rio de Janeiro, southeastern - Brazil" by Castro et al. 2014
}

\author{
JOÃO WAGNER A. CASTRO ${ }^{1,2}$, JOSÉ C.S. SEOANE ${ }^{2}$, ALINE M. DA CUNHA ${ }^{1}$, JULIA V. \\ MALTA ${ }^{1}$, CAMILA A. DE OLIVEIRA ${ }^{1}$, STELLA R. VAZ ${ }^{2}$ and KENITIRO SUGUIO ${ }^{3}$ \\ ${ }^{1}$ Laboratório de Geologia Costeira, Sedimentologia e Meio Ambiente/LAGECOST, Museu Nacional, Universidade \\ Federal do Rio de Janeiro/UFRJ, Quinta da Boa Vista, São Cristovão, 20940-040 Rio de Janeiro, RJ, Brazil \\ ${ }^{2}$ Programa de Pós Graduação em Geologia, Departamento de Geologia, Universidade Federal do Rio de Janeiro, \\ Avenida Athos da Silveira Ramos, 274, Cidade Universitária, Ilha do Fundão, 21941-916 Rio de Janeiro, RJ, Brazil \\ ${ }^{3}$ Instituto de Geociências, Universidade de São Paulo/USP, Rua do Lago, 562, \\ Cidade Universitária, 05580-080 São Paulo, SP, Brazil
}

Manuscript received on January 3, 2018; accepted for publication on April 17, 2018

\begin{abstract}
Interpretation of sea-level indicators is essential when studying paleo sea-level fluctuations during the Holocene. Sea-level indicators may have different origins, such as geological (beachrocks) and biological (vermetids and barnacles). In order to reconstruct paleo sea-level, it is necessary to attribute an indicative meaning to each sea-level indicator. This paper aims to discuss issues raised by Angulo et al. (2016) regarding to the sea-level fluctuations curve proposed by Castro et al. (2014) to the Rio de Janeiro State coast, Brazilian southeast. The key issue that deserves posing is that local or regional curves cannot be built based on large scale (global) RSL geophysical models even in places of steady crust like Brazil. Here, we put into question the relative sea-level fluctuation curve model proposed by Angulo et al. $(2006,2016)$ to the coast of Rio de Janeiro State and Pernambuco State. It is strengthened the proposal of using different origins indicators on RSL vertical variation, georeferenced by high precision altitude GPS, adjusted by Brazilian Geodetic System benchmarks, maintained by the Brazilian Institute of Geography and Statistics - IBGE. All issues regarding the curve drawn by Castro et al. (2014) are answered based on field data, laboratory analytical techniques, radiocarbon dating as well as relevant literature.
\end{abstract}

Key words: Paleo sea-level, geological and biological indicators, sea-level fluctuations curve, RSL vertical variation.

\section{INTRODUCTION}

We appreciate Angulo et al. (2016) comments and the opportunity to discuss some important aspects related to sea-level fluctuation and coastal evolution in southeastern Brazil. Data confrontation

Correspondence to: João Wagner Alencar Castro

E-mail: jwacastro@gmail.com and controversy involving interpretation related to sea-level changes at the Brazilian coast during the Holocene are a challenge for the advancement of scientific knowledge about the subject. In the 1980s curves of relative sea-level changes worldwide during Holocene have revealed great surprises and brought up unconceivable discussions before that 
time. Among them the fact that there is no single curve of global variation even in regions of stable crust like Brazil (Martin et al. 1998). This finding has pushed for new researches aiming RSL curves all around the world. Suguio et al. (1985) have proposed that paleo sea-level have dropped from 4,0 $\mathrm{m}$ to 5,0 $\mathrm{m}$ in the last 5.500 years in the Brazilian east coast. The idea of paleo sea-level higher than the current during Holocene was accepted with a degree of reluctance since it was contrary to the United States east coast curve, which shows an ongoing ascension at the same time interval.

From the end of last century till nowadays divergences have arisen regarding data interpretation about relative sea-level curves at the Brazilian coast. Tomazelli et al. (1998) has sketched out a curve to Rio Grande do Sul State coast that diverges in some aspects from curves proposed by Suguio et al. (1985) for other regions along the Brazilian coast. The Rio Grande do Sul State curve shows that the sea would have risen in the last 2.000 yrs. According to curves of Salvador (Bahia State), Santos (São Paulo State) and Itajaí (Santa Catarina State) the sea-level would have dropped in the same time interval. Angulo et al. (2006) expressed doubts on the high frequency oscillations of 200 to 300 years proposed in those curves. Martin et al. (1998) have questioned the application of a single indicator for paleo sea-level reconstruction presenting a number of counterpoints and inconsistencies. Bezerra et al. (2003) developed an envelope curve of relative sea-level fluctuation in the coast of Rio Grande do Norte State, meso tide dominated, showing oscillations after maximum Holocene high stand, which occurred at $\sim 5000 \mathrm{cal}$ yrs BP. This curve shows remarkable deviations compared with average curve to the central-south Brazilian coast.

Castro et al. (2014) have proposed a RSL curve to Rio de Janeiro coast, involving the Holocene. From the very first time in the Brazilian coast it was identified a negative record of RSL in the late
Pleistocene and early Holocene. As indicator it was used alignment of paleo beaches composed of submerged beachrocks. After that transition, a process of relatively fast sea-level rise started, like in other curves proposed to the Brazilian east coast. All indicators of RSL vertical variation identified, among them beachrocks, vermetids and barnacles, were georeferenced by high precision altitude GPS, adjusted by Brazilian Geodetic System benchmarks (RRNN), maintained by the Brazilian Institute of Geography and Statistics (IBGE). In order to mitigate the influence of possible sedimentological factors and regional tide gauge, the proposed curve was built on a restricted segment of the coast with relatively homogeneous oceanographical, geological and geomorphological characteristics.

One fact that stands out in Angulo et al. $(2006,2016)$ is the altimetric data from ancient positions of relative sea-level were plotted based on a global model of curves made by geophysical simulations proposed by Milne et al. (2005) at the Caribbean and South America. Such model covers a wide geographical extension between Jamaica (Caribbean) and Beagle Channel (Argentina). In this model the spatial variation is dominated by the influence of ice and ocean mass redistribution on sea-level change with the ice-induced effect dominating the observed north - south trend (Milne et al. 2005). Placement of indicators of few meters regarding the current zero sea-level cannot be adjusted to a global scale model of geophysical simulation since distortions and uncertainties are unavoidable. Such distortion and uncertainty are visible in the curves shown by Angulo et al. (2006) based on works of geophysical simulation by Peltier (1988) and Milne et al. (2005) around the world, including Rio de Janeiro and Pernambuco coast.

The RSL global model of postglacial shows distortions in its own conception. The main one is that relative sea-level curves in solid lines involving Pernambuco and Rio de Janeiro coasts 
points out altitude of $+4,0 \mathrm{~m}$ over current sealevel around 7.500 years BP. Such altimetric positioning contradicts almost all RSL literature in the Brazilian coastline (Suguio et al. 1985, Martin et al. 1998, Bezerra et al. 2003, Castro et al. 2014, Cunha 2016).

The Rio de Janeiro coastline is dominated by micro tide system with average spring tide of $0.90 \mathrm{~m}$ and neap tide between 0.06 and $0.025 \mathrm{~m}$ (Castro et al. 2014). The Pernambuco coastline is characterized by meso tide system with average spring tide of $2.0 \mathrm{~m}$ and neap tide of $0.7 \mathrm{~m}$. Levels of reduced tide gauge in both places are different. Oceanographical, geological and geomorphological characteristics of both states are also completely different. Therefore, curves of such distinct coastline segments cannot be the same. The manuscript by Angulo et al. (2006) is no more than a reproduction of the geophysical simulation model initially proposed by Peltier (1988) and then by Milne et al. (2005). Factors such as fluvial sediment input in the inner continental shelf as well as tide gauge variations locally affect sea-level behavior. Works developed in tide gauge stations over the wide Brazilian coastline shows, even in short-term scale, shows differences in the sea-level behavior from place to place. Of course, known factors such as glacioeustasy, tectonoeustasy and geoidoeustasy are keys to understand and interpret global scale sea-level curves.

Below, we address the issues raised by Angulo et al. (2016) in detail:

1) We agree with Angulo et al. (2016) in regard with their data and our data. Divergences and inconsistencies rely on many questions. Angulo et al. (2006, 2016) do not explain, from the methodological point of view, how vermetids altimetric position was obtained. By convenience it was used other authors altimetric information. In the curves proposed by Angulo et al. $(2006,2016)$ to Rio de Janeiro and Pernambuco coastline, altimetric data were positioned based on global model of geophysical simulation, initially proposed by Peltier (1988) and then by Milne et al. (2005). Indicators of few meters regarding the current zero sea-level cannot be adjusted to a global scale model of geophysical simulation since distortions and uncertainties are unavoidable.

2) We are sure that vermetids are indicators of vertical fluctuation of paleo sea-level. Nevertheless, indiscriminate use of certain species of Vermetidae could compromise information plotted in the vertical axis of relative sea-level fluctuation curve - RSL. According to Oliveira (2016) there are some species of Vermetidae whereby distribution related to depth could vary from middle littoral or upper part of infra littoral to $100 \mathrm{~m}$ depth. From 16 taxa existing in the Brazilian coastline, two species are wide used as indicators of vertical variation of paleo sea-level, Dendropoma irregulare and Petaloconchus varians. According to Oliveira (2016), in the south of Cabo Frio, Rio de Janeiro State, there are no current correspondent of Petaloconchus varians to obtain the relationship between those species and the current relative sealevel. Thus, it is used Phragmatopoma caudata to estimate paleo sea-level at the time corresponding to fossil vermetids. However, Spotorno-Oliveira et al. (2016) have recorded the occurrence of Petaloconchus varians in several places of the region of Ilha Grande Bay, south coast of Rio de Janeiro State. They are characterized by a complex structure formed by alive individuals in the upper layer and dead individuals in the lower layer along with the bedrock. From the geomorphological point of view, they are positioned in the middle littoral on the rocky coasts and on the infra littoral they form "microatoll". The presence of alive homologous in this Brazilian coastline segment was also recorded by Spotorno- 
Oliveira et al. (2016) and Oliveira (2016). It was possible to obtain at the field vertical ranges of occurrence of species relating to alive homologous at current sea-level and fossil vermetids, all placed above that level. After being identified, it was defined altimetric ranges by high precision GPS (static method), proposed by Castro et al. (2014). Adjustments were made based on the Brazilian Geodetic System benchmarks (RRNN), maintained by the Brazilian Institute of Geography and Statistics - IBGE. With respect to Angulo et al. (2016) question about Laguncularia racemosa as Vermetidae specie, please note that it is just a typing error in the article by Castro et al. (2014). We have advised a master thesis involving vermetids and sea-level variations which means that we would not make that kind of serious mistake.

3) Today we have no doubt that beachrocks (except the organic category) are great indicators of RSL. This observation is supported by the doctoral thesis of Malta (2017) about genesis, petrography, lithification process, $\delta^{13} \mathrm{C}$ $\delta^{18} \mathrm{O}$ stable isotopes and geochronology of beachrocks from Rio de Janeiro State coastline. It also corroborates with information obtained by Mauz et al. (2015) and Malta (2017). From the genetic view, beachrocks can be divided into four categories according to its process of lithification: (a) precipitation of highly magnesian calcite and aragonite from seawater due to high temperature, oversaturation and/or $\mathrm{CaCO}_{3}$ evaporation; (b) precipitation of calcite and aragonite from mixture of groundwater and seawater; (c) precipitation of magnesian calcite and aragonite by $\mathrm{CO}_{2}$ degassing from sediment and pore water; (d) precipitation of micrite calcium carbonate as a product of microbiologic activity (Mauz et al. 2015, Malta 2017). We considered that the lithification process of beachrocks (paleo beach) fit into (a), (b) and (c) categories. Most part of beachrocks from Rio de Janeiro State fits into categories (b) and (c). They were lithified in inter tide zone, exhibiting paleo beach or post-paleo beach environment. This observation was supported by modern analytical techniques such as cathodoluminescence, stable isotopes, SEM and EDS. It is considered that all beachrock outcrops used in RSL curve proposed by Castro et al. (2014) are geological indicators of relative sea-level fluctuation during Holocene. Angulo et al. (2016) made a misunderstanding regarding beachrocks' age suggesting that they were formed in thousands of yrs. According to Malta (2017) beachrocks can be formed only in hundreds of years. Indeed, it is not rare the occurrence of modern objects completely cemented by carbonate cement (Malta 2017). Beachrock sedimentary structures and their texture characteristics are representative of beach depositional environment due to hydrodynamic conditions during deposition and are usually well preserved. Radiocarbon age differences between cement and mollusk shell in beachrocks are not very substantial. It was verified on the worldwide literature that these rocks are almost all from Holocene (Malta 2017). In Brazil the beachrocks' age vary from $\sim 1.250$ to 11.900 cal yrs BP. The oldest ones can be found in the Rio de Janeiro coastline and the newest ones in the Brazilian northeast. At the Rio de Janeiro coastline all outcrops were lithified before coastal upwelling, around 3.000 cal yrs BP (Malta 2017). They are laid out submerged and surfaced aligned parallel to the current coastline. In the light of that information complemented by measurements obtained by geodesic GPS of high precision as well as depth data assessed by echobathimeter, it can be inferred that those beachrocks were lithified in conditions of sea-level between $-4.5 \mathrm{~m}$ in 
the transition from Pleistocene to Holocene and $+1.5 \mathrm{~m}$ before coastal upwelling arrival, when lithification process was interrupted. The paleoenvironmental reconstitution model developed by Castro et al. (2012) suggests that most submerged beachrocks in the Rio de Janeiro coastline are part of ancient drowned barrier island. However, it is not ruled out that neotectonics of late Pleistocene have contributed with altimetric and bathymetric position of those rocks. Therefore, we are sure that beachrocks are great indicators of vertical sea-level variation, except the organic category (d) resulting from precipitation of micrite calcium carbonate as a product of microbiologic activity. With respect to beachrocks age in Castro et al. (2012) we can inform that all adjustment was made based on new radiocarbon dating and can be found in the work by Castro et al. (2014).

4) We are convinced that mollusk shell cannot give precise information about vertical variations of paleo sea-level. However, they could give very important indirect information about upper limit (horizontal plane) of sealevel. Castro et al. (2014) have associated horizontal projection of maximum Holocene transgression in the Rio de Janeiro State coastline based on the presence of mollusk shell deposited in ancient lacustrine system edge. Cunha (2016) suggest that accumulation of mollusk shell deposited in current coastal marsh edge represents the most important record of positive oscillation of relative sea-level during Holocene in the Brazilian southeast. Radiocarbon dating ${ }^{14} \mathrm{C}$ in Anomalocardia brasiliana mollusk shell have shown ages between 6.335 and $4.800 \mathrm{cal}$ yrs BP. According to Cunha (2016) this time interval corresponds to the beginning of marine transgression, maximum Holocene peak (climatic optimum) and the sudden relative sea-level lowering. According to Castro et al.
(2014) and Cunha (2016) the sudden sea-level lowering in this region has caused widespread killing of mollusk shells many of them in position of life. The subsequent relative sealevel lowering has caused the formation of paleo lagoons, beach ridges and marsh resulting the progradation of coastline till nowadays. The Holocene marine transgression in most part of Rio de Janeiro coastline was controlled by geological and geomorphological conditions imposed by the Paleoproterozoic basement, Barreiras Formation, as well as beach ridges surrounding the hydrographic basins of Una, São João, Macaé and Paraíba do Sul rivers. The paleoenvironmental model proposed by Castro et al. (2014) and Cunha (2016) shows the basins of Una river and São João river flooded by Holocene marine transgression which has occurred between 6.335 and 4.800 cal yrs BP. During this episode, the relative sea-level has reached a maximum height between +2.50 and $+3.0 \mathrm{~m}$ above the current level

5) On the use of geodesic GPS of high precision when studying relative sea-level variations: whereas Angulo et al. (2016) acknowledge we have used "GPS trackers", they fail to mention specifically post-processing GPS orthometric corrections, which not only lower positional error but also levels data to a common orthometric datum. Further, they argue paleo-sea level are "not related to the accuracy of determining the present mean-sea level", which while true, does not preclude present-day sea-level to be precisely defined in order to apply the knowledge of the sea-level variation to coastal management (e.g. NOAA's Vertical Datum Transformation effort and Natural Resources Canada's Height Reference System Modernization). NOAA anticipated using the GPS for sea-level measurements: "data from new altimeter satellites combined with Global Positioning System geodesic data 
will soon clarify this uncertain situation". Moreover, NOAA states that "for application to climate change scenarios and to inundation analyses and modeling, it is critical that all elevations and depths be referenced to the same datum, regardless of source". They also recommend survey-grade equipment using GPS data in a kinematic differential mode to obtain orthometric heights precise to $30 \mathrm{~mm}$ $40 \mathrm{~mm}$ RMSE, as we have used. In summary, while we agree with Angulo et al. (2016) that "paleo-sea level reconstructions must consider the vertical distance between a given indicator and its present homologous one", we also recognize several other factors that could have a role in this distance (e.g. neotectonics). We did not yet attempt to model such factors but we strongly believe having measurements tied to an orthometric datum will help future analysis. According to Castro et al. (2014), altimetric data collection on the ellipsoid as well as millimetric precise coordinates $(\mathrm{x}, \mathrm{y})$ were carried out by GPS Pro Mark 2. On the occasion of survey surfaced indicators (beachrocks) it was used static method based on echo bathimeter.

\section{CONCLUSIONS}

Unfortunately, we are forced to strongly disagree with Angulo et al. (2016). We believe the data shown in our work were misinterpreted. Such criticism does not contribute for the scientific knowledge progress around the topic discussed. We must highlight the criticism made is not supported by field work in the Rio de Janeiro State coastline. We also believe that our results are convincing and have been used to support many doctoral and master theses. In this way, it contributes to better understanding of the relative sea-level fluctuations in the Rio de Janeiro coastline. Moreover, such research includes high precision altimetric data collection, scuba diving, laboratory analytical techniques and geochronological information complemented by clear and objective methodological procedures.

The curve proposed by Angulo et al. (2006) to the Rio de Janeiro coastline reproduces the geophysical simulation model initially proposed by Peltier (1988) and then Milne et al. (2005) which was applied in many places around the world including Rio de Janeiro and Pernambuco's coastline. Tide gauge levels in both coastal segments are distinct. Geological and oceanographical characteristics are also distinct, therefore the curve could not be the same for both sites.

We support the suggestion of using indicators from different origins when studying RSL vertical variation, especially beachrocks of the three inorganic categories above identified as well as vermetids of Dendropoma irregular and Petaloconchus varians species. Although Anomalocardia brasiliana mollusk shell does not provide accurate information about paleo sealevel vertical position, it could be useful to define upper limit (horizontal position) of ancient sealevel. The great sea flood caused by the maximum Holocene transgression in the Rio de Janeiro coastline is identified by the presence of mollusk shell deposited on the edge of ancient lagoon and bay systems. Every RSL indicators must be georeferenced by high precision altitude GPS and adjusted by Brazilian geodetic system benchmarks or other system with similar properties in other parts of the world. Therefore, RSL studies would be also useful when predicting future sea-level for coastal management programs.

\section{ACKNOWLEDGMENTS}

This manuscript is dedicated to Prof. Louis Martin and Prof. Kenitiro Suguio by their great contribution to relative sea-level fluctuation studies in the Brazilian coast. 


\section{REFERENCES}

ANGULO RJ, GEANNINI PF, SOUZA MC AND LESSA GC. 2016. Holocene paleo-sea level changes along the coast of Rio de Janeiro, southern Brazil: Comment on Castro et al. (2014). An Acad Bras Cienc 88: 2105-2111.

ANGULO RJ, LESSA GC AND SOUZA MC. 2006. A critical review of Mid- to Late Holocene sea-level fluctuations on the eastern Brazilian coastline. Quat Scien Rev 25: 486506.

BEZERRA FH R, BARRETO AMF AND SUGUIO K. 2003. Holocene sea-level history on the Rio Grande do Norte State coast, Brazil. Mar Geol 196(1-2): 73-89.

CASTRO JWA, SUGUIO K, CUNHA AM DA, GUEDES E, TÂMEGA FT DE S AND RODRIGUEZ RR. 2012. Rochas de praia (beachrocks) da ilha de Cabo Frio, Arraial do Cabo: registro geológico ímpar da transição Pleistoceno - Holoceno no Estado do Rio de Janeiro. Anu Inst Geoc UFRJ 35(1): 236-241.

CASTRO JWA, SUGUIO K, SEOANE, JCS, CUNHA AM AND DIAS FF. 2014. Sea-level fluctuations and coastal evolution in the state of Rio de Janeiro, southeastern Brazil. An Acad Bras Cienc 86: 671-683.

CUNHA AM. 2016. Reconstituição paleoambiental das variações do nível relativo do mar durante a transgressão holocênica na bacia hidrográfica do rio Una, região de Cabo Frio - Estado do Rio de Janeiro. 2016. PhD Thesis, Universidade Federal do Rio de Janeiro, Rio de Janeiro, $188 \mathrm{p}$.

MALTA JV. 2017. Rochas de praia "beachrocks" do litoral do Estado do Rio de Janeiro: Aspectos geológicos, geocronológicos e paleoambientais. 2017. PhD Thesis, Universidade Federal do Rio de Janeiro, Rio de Janeiro, $119 \mathrm{p}$.

MARTIN L, BITTENCOURT ACSP, DOMINGUEZ JML, FLEXOR JM AND SUGUIO K. 1998. Oscillations or not oscillations, that is the question: comment on Angulo RJ and Lessa GC "The Brazilian sea-level curves: a critical review emphasis on the curves from the Paranaguá and Cananeia regions". Mar Geol 150: 179-187.

MAUZ B, VACCHI M, GREEN A, HOFFMANN G, COOPER A. 2015. Beachrock: A tool for reconstructing relative sea level in the far-field. Mar Geol 362: 1-16.

MILNE GA, LONG AJ AND BASSETT E. 2005. Modeling Holocene relative sea-level Observations from the Caribbean and South America. Quat Sci Rev 24(10-11): 1183-1202.

OLIVEIRA CA. 2016. Estudo dos vermetídeos como bioindicadores de variações do nível relativo do mar durante o Holoceno na enseada dos Anjos - Arraial do Cabo, Rio de Janeiro. 2016. Master Dissertation, Universidade Federal do Rio de Janeiro, Rio de Janeiro, 82 p. (Unpublished).

PELTIER WR. 1988. Lithospheric Thickness, Antarctic Deglaciation History, and Ocean Basin Discretization Effects in a Global Model of Postglacial Sea Level Change: A Summary of Some Sources of Nonuniqueness. Quat Res 29: 93-112.

SPOTORNO-OLIVEIRA P, TÂMEGA FTS, OLIVEIRA CA, CASTRO JWA, COUTINHO R, IRYUC Y AND BASSI D. 2016. Effects of Holocene sea level changes on subtidal palaeoecosystems, southeastern Brazil. Mar Geol 381(1): $17-28$.

SUGUIO K, MARTIN L, BITTENCOURT ACSP, DOMINGUEZ JML, FLEXOR JM AND AZEVEDO AEG. 1985. Flutuações do nível relativo do mar durante o Quaternário superior ao longo do litoral brasileiro e suas implicações na sedimentação costeira. Rev Bras Geoci 4: 273-286.

TOMAZELLI LJ, VILLWOCK JA, DILLENBURG SR, BACHI FA AND DEHNHARDT BA. 1998. Significance of present-day coastal erosion and marine transgression, Rio Grande do Sul, southern Brazil. An Acad Bras Cienc 70: 221-229. 